Advances in Social Science, Education and Humanities Research, volume 191

Asian Association for Public Administration Annual Conference (AAPA 2018)

\title{
THE COLLABORATIVE GOVERNANCE MODELS ON EDUCATIONAL AUTONOMY IMPLEMENTATION IN JAKARTA (CASE STUDY IN SMPN and SMAN, SOUTH JAKARTA)
}

\author{
Retnowati WD.Tuti $^{1}$; Kurniasih Mufidayati ${ }^{2}$ \\ Magister of Administrative Science (MIA) \\ FISIP , Muhammadiyah Jakarta University \\ 1retnowatiwdtuti@yahoo.com,2kmf0219@gmail.com
}

Keywords : educational autonomy, collaboration model, collaboration level

\begin{abstract}
In general, the participation and collaboration of stakeholders is a fundamental factor in the implementation of school autonomy in schools. Collaboration of school stakeholders is essential for strengthening education autonomy in schools and for improving the quality of education of the nation's generation. This is what prompted the research on Collaboration in the autonomy of education at public junior high and senior high schools in South Jakarta. Using a qualitative approach with descriptive method, this study aims to answer the problem of research is 'How is Collaboration Model in Autonomous Education at Public Junior High School (SMPN) and Senior High School (SMAN) In South Jakarta?'. The study was conducted on a number of junior and senior high schools in South Jakarta. Wanna's Collaborative Governance Theory (2008) is the foundations of this research. The concept of collaboration degree and models has been used to see the degree and model on educational autonomy. This research concludes that the collaboration models is done for collaboration between government and the third sector and collaboration between government and citizen. Meanwhile, the degree of collaboration is located between lowmiddle collaboration level.
\end{abstract}

\section{Introduction}

Law No. 20 of 2003 on National Education System, article 3 states that the purpose of national education is to develop the potential of learners to become human beings who believe and fear Allah Almighty, have a noble character, healthy, knowledgeable, capable, creative, independent, and be a democratic and responsible citizen. This article becomes an important foundation in the process of improving the quality of national education through education autonomy at the school level as an educational unit that directly manages education for learners.

Autonomy in the field of education, indicating the use of authority does not stop at the district / city level, but to the level of schools as the spearhead of the implementation of education. In this case schools are given the authority and independence to organize and manage their own schools on the initiative of the school, and participatory decision making in order to achieve the goal of the school, which is to achieve good learning results in order to realize the quality of higher education. 
Several studies indicate that there is a problem in the implementation of education autonomy in schools that stems from the role of stakeholders. Schools as social organizations education providers have stakeholders both internal and external school organization. The main internal parties are principals and teachers who will be the implementers of teaching and learning activities and determine the performance of school organizations. Other internal parties are the provincial and district / municipal governments in this case the education and tribal offices of the education service, as directors and facilitators. The external party includes the support of parents and the community.

In general, the participation and collaboration of stakeholders is a fundamental factor in the implementation of school autonomy in schools. Korten said with participation, the development can be run to improve human dignity as stated in the idea of "people centered development". Donahue and Zeckhauser, declare that government employees will be able to perform their public duties properly through collaboration with private parties, individuals or community groups. His research in several schools also shows the importance of government collaboration with school stakeholders.

Ai Shoruka (2008) in his studies on School Based Management in East Asia, including Indonesia, concluded that educational partnerships at the school level are still confusing and the participation of the community in school management has not been well stimulated. Another study from World Bank (2007) in various countries concluded that the key to successful implementation of School Based Management is the strong participation of stakeholders in the implementation of education processes in schools, especially principals, teachers and the community.

JRO Cabardo in his study (2016) in the Division of Davao del Sur showed that the level of participation of the school stakeholders to the different schoolinitiated activities was found to be moderate and the level of SBM implementation was found to be at Exceeding the Minimum Standard. This study means there're so many challenges to improve school stakeholders participation on SBM implementation. Heyward, M., Cannon, R.A., \& Sarjono. (2011) in their study, with the title Implementing School-Based Management in Indonesia, concluded that the school program was explicitly based on government policy; and the program was school based and involved members of the entire school community: principals, teachers, staff, parents, and community members. The study means that all school stakeholders have important role in SBM implementation.

Ministries of education and culture at the beginning of the school year 2017/2018 encourages schools to collaborate with various parties and learning resources outside of school to improve the quality of education in schools. On the 
first day of school in July 2017, starting the new school year 2017/2018, Ministries of education and culture urges parents to come to meet the homeroom teacher to obtain information about the introduction of school environment program for new students, intrakurikuler, kokurikuler, extracurricular program, and school's code of conduct, as a form of school collaboration and parents.

Some problems still hamper the SBM implementation as educational autonomy form at the school level, such as the participation and collaboration of stakeholders that have not been implemented proportionately. From the phenomenon of Pustekom Dinas Pendidikan (2010) and preliminary interviews (2015), Jakarta still shows the uniformity in understanding the meaning of the implementation of educational autonomy at the school level. Examples of cases found are the principals who have received several materials on the nature of School Based Management (SBM) as a form of educational autonomy in schools, it has not succeeded 100 percent yet. In fact, there were a lot of poor understanding of the form and examples of SBM implementation. Many parents and students do not understand about the educational autonomy in SBM.

Collaboration between school stakeholders is essential for strengthening educational autonomy in schools and for improving the quality of education of the nation's generation. This has prompted research on School Stakeholders Collaboration in the management of public schools in Jakarta. Using a qualitative approach with descriptive method, this study aims to answer the problem of research which is 'How is the Collaboration Model on Educational Autonomy In Jakarta?'. The research was conducted at 6 junior and high schools in South Jakarta.

\section{Collaborative Governance Theory}

In the last two decades, governments around the world are developing a new strategy for building effective governance known as Collaborative Governance. Through collaborative strategy, the government seeks to involve multiple stakeholders in a joint forum to jointly seek consensus in decisionmaking processes / policies or in the provision of public goods. In its implementation, this collaborative public service management includes in the form of participative governance which actively involves the community in decision making and activities of the government.

Donahue and Zeckhauser (2011), said on Collaborative Governance:

"The term refers to instances in which government officials seek to fullfill a public mandate through collaboration with private firms, groups or individuals." 
The view above shows that the government in carrying out its duties collaborative public needs have to collaborate with other parties such as private companies or other groups. One of the motivations for collaboration is to produce better outcomes. Donahue and Zeckhauser have conducted studies on pre-school education services, in six cities. Here are the results of research for pre-school education services:

\begin{tabular}{|l|l|}
\hline Cities & Preschool Education \\
\hline Boston & All services delegated to a single non profit \\
\hline Colorado Springs & All services delegated to a single non profit \\
\hline Louisville & All services delivered by public school system \\
\hline Miami & $\begin{array}{l}\text { Roughly half of services delivered by public agency, the other } \\
\text { half by a mix non profit and faith-based organization }\end{array}$ \\
\hline Oakland & Not enough data \\
\hline Raleigh & All services delegated to a single non profit \\
\hline
\end{tabular}

Table 1 : Collaborative Research Results by Donahue and Zeckhauser

(Source : Donahue, John D and Zeckhauser,Richard J ; 2011)

The key collaboration of this strategy is interpreted as an agreement of two or more stakeholders to share information, roles, functions and responsibilities in a mutually agreed partnership and partnership mechanism. Collaborative can also be interpreted as a form of partnership in achieving common goals that work across sectoral boundaries and involve relationships from various parties. Therefore, the collaboration is built on the values of mutually beneficial relationships between the parties.

Munt, gives the keyword of the meaning of collaboration, which is 'working together'. The keyword describes the existence of a joint working element between a number of stakeholders to achieve a common goal. Collaboration occurs because of the cooperation of stakeholders. This meaning is similar to that of Wildavsky (1973) which describes that there are 6 (six) dimensions of the concept of collaboration that distinguish from other conceptions. The first dimension, in collaboration is cooperation in building communality, developing consistency and joint activities among stakeholders. In the second dimension, collaboration is placed as a process in negotiating in the search for compromise and reaching agreement. Collaboration in the third 
dimension concerns the supervision of co-driven rules with centralized coordination. In the fourth dimension, collaboration involves power and encouragement as an ability to achieve certain goals or trends in a form of engagement. Fifth dimension, collaboration is also related to future commitments and trends, prospective habits, in a planning or preparation in building a joint activity. In the latter dimension, collaboration builds involvement in developing internal and personal motivation to commit to the projects, decisions, organizational direction or strategic goals. These six dimensions are exclusively stand-alone dimensions.

Conceptually, Wanna (2008) explained that collaboration can be reviewed in 2 (two) aspects, namely the scale or degree of collaboration and the context, goals and motivations underlying a collaborative activity. On a scale or degree of collaboration, the categorization pattern is judged either by evidence or motivation, which defines the scale of collaboration as the escalation ladder of commitment-from the lowest level to the highest level of collaboration. Then in context, goals and motivation, collaboration can be distinguished by the level of desire and motivation that shows the alternate areas or approaches underlying collaboration creation.

\begin{tabular}{|c|c|}
\hline Degree of Collaboration & Who is involved and what is the activity? \\
\hline $\begin{array}{l}\text { Highest Level: } \\
\text { - High commitment to collaborate } \\
\text { - The highest management or political risks }\end{array}$ & $\begin{array}{l}\text { - Transactions that are transformative } \\
\text { between the actors' networks. } \\
\text { - Involvement and empowerment is } \\
\text { done substantively } \\
\text { - Seek high degree of consensus and } \\
\text { cooperation among actors and } \\
\text { stakeholders } \\
\text { - The development of coalitions } \\
\text { between government andnon- } \\
\text { government actors. }\end{array}$ \\
\hline $\begin{array}{l}\text { Middle Level with the highest level: } \\
\text { - Strong commitment to collaborate } \\
\text { - High management or political risks }\end{array}$ & $\begin{array}{l}\text { - Strong involvement of stakeholders in } \\
\text { decision-making or policy-making } \\
\text { processes and their implementation. } \\
\text { - Transfer decision-making capacity to } \\
\text { clients } \\
\text { - More complex innovations in the } \\
\text { policy delivery process. }\end{array}$ \\
\hline $\begin{array}{l}\text { Intermediate Level } \\
\text { - Commitment to involving and involving }\end{array}$ & $\begin{array}{l}\text { - Formal commitment among } \\
\begin{array}{l}\text { institutions in consultation and } \\
\text { collaboration }\end{array}\end{array}$ \\
\hline
\end{tabular}




\begin{tabular}{|c|c|}
\hline $\begin{array}{l}\text { various parties } \\
\qquad \text { Middle risk of management or politics }\end{array}$ & $\begin{array}{l}\text { - The joining of the Government } \\
\text { Strategy } \\
\text { - Formal training involvement and joint } \\
\text { funding initiatives. }\end{array}$ \\
\hline $\begin{array}{l}\text { Medium-Low Level: } \\
\text { - The operational form of collaboration is only } \\
\text { oriented towards the completion of the work. } \\
\text { - Some risk of management or politics }\end{array}$ & $\begin{array}{l}\text { - Co-production } \\
\text { - Technical development in delivery } \\
\text { - Support in fulfillment of obligations } \\
\text { - Consulting directly to clients after } \\
\text { deliver and complaint system. } \\
\text { - Using systematic evaluation data. } \\
\text { - Announce to the public based on } \\
\text { consumer choice of the specified } \\
\text { target. }\end{array}$ \\
\hline $\begin{array}{l}\text { Low level: } \\
\text { - Operation is slightly adaptable } \\
\text { collaboration } \\
\text { - Low risk management or politics }\end{array}$ & $\begin{array}{l}\text { - Periodic improvements using } \\
\text { consultative processes } \\
\text { - Useofdiscussionandfeed } \\
\text { mechanisms with clients } \\
\text { - Seek information about the needs and } \\
\text { expectations of others. }\end{array}$ \\
\hline
\end{tabular}

Table 2. Collaboration Scale Table

(Source: Wanna, 2008)

Wanna (2008) revealed that there are 4 (four) forms of collaboration that accommodate the cooperation relationship both within the internal government itself and between the government and external in the implementation of government duties and responsibilities, namely (1) internal government collaboration, involving inter-agency and bureaucrats, (2) intergovernmental collaboration, which involves different agencies of jurisdiction, (3) collaboration between government and external third parties, particularly related to procurement of goods and services; and (4) collaboration between government and individual citizens. The four forms of collaboration show that collaboration begins with a relationship between two or more stakeholders.

From the description above and see the four models of collaboration, the concept is suspected to emerge as a response to the development of knowledge and institutional capacity in society. Knowledge has encouraged the development of institutional capacity and specialization in the midst of society amid the complexity of the problems and challenges faced by the government in making policies and providing public services to the public. Therefore, when the government's duties and responsibilities cannot be done by the government itself and there are other parties outside the government who have the ability to support 
government work, the involvement of external parties should be facilitated in supporting the government's work in carrying out its duties and responsibilities.

Wanna Collaboration concept of which has been described above, will be the framework in this study. The concept of degree of collaboration will be used to see the degree of collaboration between the community, parents and school. While the concept of four forms of collaboration from Wanna will be used to analyze collaborative models between communities, parents and schools.

\section{Research Method}

The research took place at SMPN and SMAN South Jakarta on January 2017. Qualitative Approach with Descriptive Method used in this research. Data collected by interviews, observation and documentation techniques. Informants were selected using the purposive method. Informants consisted of school stakeholders of the best SMPN and SMAN in South Jakarta. It because of the best schools are schools that meet the excellent School category according to the National Education Department compared with other schools. Therefore, the best schools should be pilot projects and benchmark for other schools.

\section{Collaboration Degrees of the Implementation of Autonomy of Education in Schools}

\section{School Planning; Low Collaboration}

From the findings and discussion of the results of the research, it is constructed that an orientation of success or failure to realize the plan of all school activities is based on the analysis on the position and function of APBS by a school using the perspective of School Work Plan and APBS it developed. The research result showed that the budget map and activities can be funded by the school and able to be implemented in accordance with the type of program and adequate funding and can be implemented in accordance with the time and the results.

In general there is a weak situation of participation from parents and even school committees themselves in asking for the allocation of fees that have been determined especially to refuse. This condition is subjectively caused by several things, namely the busyness of parents who are so high that they do not have time for their son / daughter's school, parents 'concerns about the pressure or threats to their sons / daughters in school as a result of parents' critical attitude and parental ignorance about the important role of parents in the success of all school

activities. 


\section{School Program Implementation ; Medium Collaboration}

In field observation the level of involvement and cooperation among the community, parents and schools seem to be working well. Teachers in the classroom in the educational process create various of activities that must be done by students in the school environment, as well as outside the school in person or in groups. In this series of activities, parents are able to facilitate such activities optimally, especially for activities conducted outside the school. Similarly, parents who are always ready to participate directly accompany their children as a form of support for activities like this. For this stage, it appears that collaboration conditions are intermediate collaboration.

\section{School Resources Management; Intermediate-Low Collaboration}

The Minister of Education and Culture has issued regulations of the ministry of education and culture Number 75 year 2016 regarding School Committee. One arranged in the regulation is the participation of school committees to contribute and help to schools. This legislation encourages the collaboration of school committees and schools in search of resources and funds to support student programs and activities in schools. Field observations show that school committees have sought to encourage parents and communities to contribute their resources, but the distribution of information conducted by school committees to parents and communities is weak and limited. Sometimes the dissemination of this information is so limited that not all parents are aware of resource management issues that need immediate response. Whereas on the side of the parents themselves, such great potential and desire to help school. Therefore, special attention needs to be given to school committees to strengthen access and distribution of information in the management of school resources to parents and the community so that such potential empowerment of parents and students can be utilized optimally. For this phase, the condition of collaboration is an intermediate-low-level collaboration.

\section{Supervision and Evaluation of School Management ; Low Collaboration}

In this fourth form of collaboration, in general from field observations, stakeholders such as school committees and parents have many disadvantages, particularly to supervise and evaluate school management. Volunteering activities from school committees and parents are a major obstacle to carrying out this collaborative work. Not to mention the skill and the ability of school committees and parents in carrying out supervisory and evaluation roles that are slightly below the teacher or principal. As a result of this situation, it is generally seen that school management in this case principals and teachers dominate more work in 
this field than other stakeholders. Experience and maturity in performing the tasks become the key point of dominance of school managers in supervision. For this phase, the condition of collaboration is low collaboration.

\section{Collaborative Model of Implementation of Education Autonomy in Schools}

Analyzed with Collaborative Model Theory (Wanna), found collaboration model of the 3rd and 4th, because in the implementation of education autonomy in schools involving the government (school) with the citizens of the school and community, even third parties. The 3rd and 4th models are as follows:

3) collaboration between government and external third parties, especially in relation to procurement of goods and services;

4) collaboration between government and individual citizens

Collaboration of all school stakeholders is a very important factor and a basic capital for the process of change and development of schools towards the better. Of course, to gain strong support from them, it takes a meaningful engagement in every decision taken. Through engagement and collaboration work is expected to increase motivation and satisfaction, foster mutuality, increase confidence and create commitment to all decisions that are taken not only for parents but also for teachers, principals and other related parties. In supporting the collaboration of school stakeholders, there is a potential for internal and outside school. So the collaborative model of education autonomy in school, in terms of school program management can be described as below.

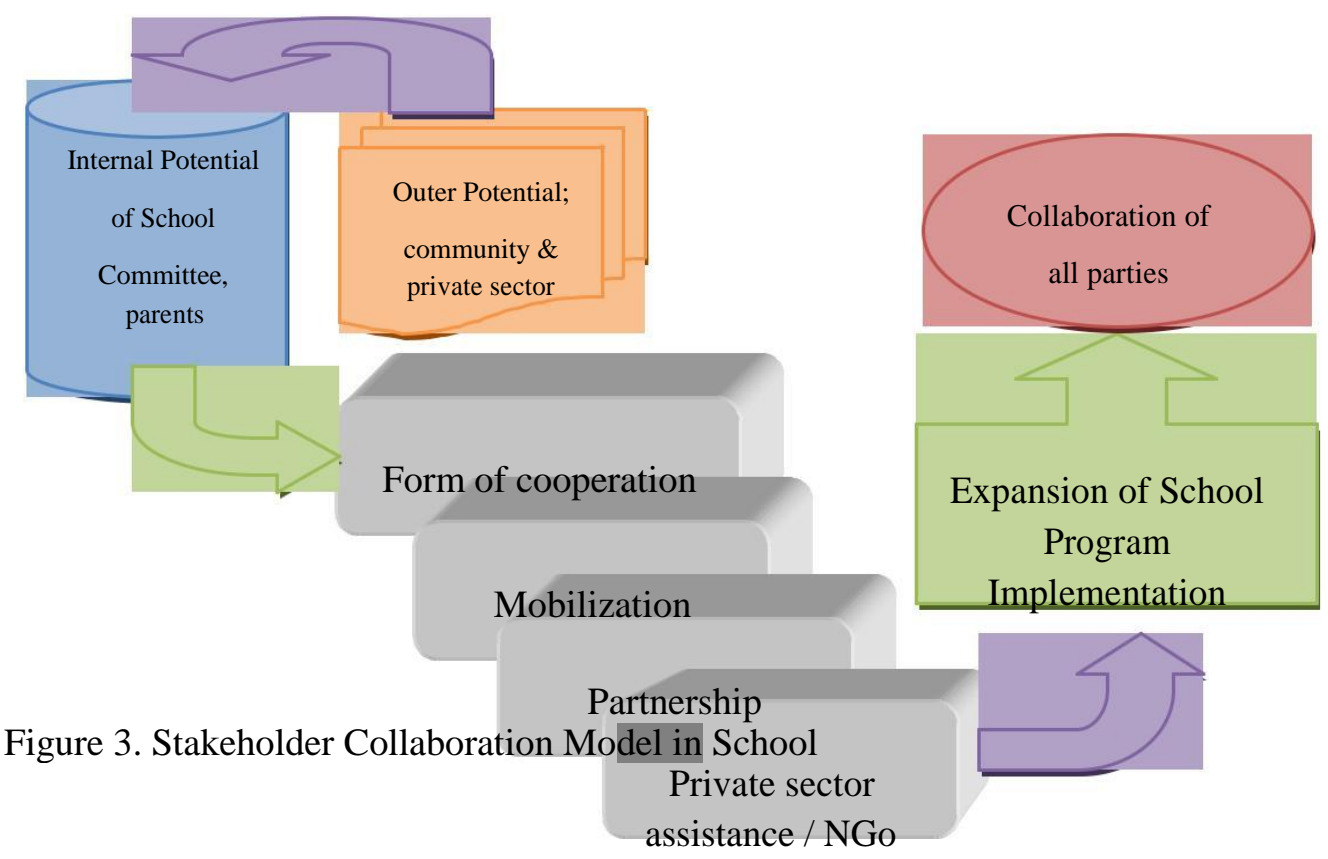




\section{Conclusion}

Collaboration pattern in juior high and senior high school management in South Jakarta was carried out in four school management activities (1) collaboration in school planning, (2) collaboration in school program implementation, (3) collaboration in school resource management, and (4) ) collaboration in supervision and evaluation of school management. Collaborative portraits for each built relationships, no one has shown high collaboration, but are located between low-to-intermediate collaborations.

The collaboration of stakeholders in junior high and senior high school management in South Jakarta should continue to be encouraged by various efforts to improve the authority of the community, in this case the school committee and parents, in order to achieve a continuum of intermediate collaboration. To create a positive collaboration, it is necessary to apply Collaborative Advantage concept so that the output and outcome of school autonomy policy is better. So that it can drive the success of educational autonomy policy in Indonesia.

It needs to be further developed in subsequent research on continuum theory and collaborative models of educational stakeholders in the autonomy of educational management at the school level. A serious study of academic texts should be developed to add the collaborative aspects of educational stakeholders to related policies. As it is proven to improve the management of education and better educational services, it is not enough just with the article 'community participation', but all stakeholders must realize harmonious and positive collaboration.

\section{References}

Ansell, Chris and Alison Gash, 2007, Collaborative Governance in Theory and Practice, Journal of Public Administration Research and Theory, vol 18, p.543-571.

Baedhowi, 2007, Kebijakan Otonomi Daerah Bidang Pendidikan ; Konsep Dasar dan Implementasi, Semarang, UPT UNNES Press

Baedhowi, 2004, Implementasi Kebijakan Otonomi Daerah Bidang Pendidikan; Studi Kasus di Kabupaten Kendal dan Kota Surakarta, Jakarta, Disertasi Doktor, UI

Donahue, John D and Zeckhauser,Richard J, 2011, Collaborative Governance ; Private Roles for Public Goals in Turbulent Times, USA, Princeton University Press 
Education Human Development Network, What Is Scholl-Based Management?, 2007, The World Bank, Washington, DC

Hasbullah, 2006, Otonomi Pendidikan, Jakarta, PT. Raja Grafindo Persada

Heyward, M., Cannon, R.A., \& Sarjono, 2011, Implementing school-based management in Indonesia, RTI Press publication No. OP-0006-1109, Research Triangle Park, NC: RTI Press. Retrieved [date] from http://www.rti.org/rtipress

Huxham, Chris \& Vangen, Siv, 2005, Managing to Collaborate ; The Theory and Practice of Collaborative Advantage, Routledge 2 Park Square, Milton Park, Abigdon, Oxon (OX 14 4RN)

John, 2004, On Collaborative Governance, Working Paper 2, March 2004, John F. Kennedy School of Government, Harvard University

John W, Creswell, Research Design; Qualitative and Quantitative Approaches, 1994, New Delhi, India, Sage Publications, Inc.

JRO Cabardo, 2016, Levels of Participation of the School Stakeholders to the Different SchoolInitiated Activities and the Implementation of School-Based Management, Journal of Inquiry \& Action in Education, 8(1) year 2016

Lembaga Administrasi Negara, 1999, Administrasi Negara, Demokrasi dan Masyarakat Madani, Jakarta, CV.Riana

Moleong J, Lexy, 2000, Metodologi Penelitian Kualitatif, Bandung, PT. Remaja Rosdakarya

Mufidayati,Kurniasih, 2012, Implementasi Kebijakan Manajemen Berbasis Sekolah (MBS) pada Sekolah Dasar (SD) dan Sekolah Menengah Pertama (SMP) Negeri Rintisan Sekolah Bertaraf Internasional di DKI Jakarta, Jakarta, Disertasi Doktor, UI

O’Leary, Rosemary, Lisa Blomgren Bingham, et.all, 2009, Public Managers in Collaboratin dalam The Collaborative Public Manager-New Ideas for Twenty-first Century, Editor: Rosemary O’Leary dan Lisa Blomgren Bingham, Washington, D.C: Georgetown University Press, USA, p. 3

Richard Munt, 2003, Building Collaboration, Stronger Families Learning Exchange Bulletin No.

$$
\text { 3, Winter, pg. 6-8, dari http://www.aifs.gov.au/sf/pubs/bull3/rm.html. }
$$

Wanna, John, 2008, Collaborative government: meanings, dimensions, drivers and outcomes 
Advances in Social Science, Education and Humanities Research, volume 191

dalam

Collaborative governance: a

new era of public

policy in 
Australia? Editor: Janine O’Flynn dan John Wanna, Camberra: ANU E Press, Australia

The World Bank, 2007, Impact Evaluation for School-Based Management Reform, Washington DC, The World Bank 